\title{
Population Member
}

National Cancer Institute

\section{Source}

National Cancer Institute. Population Member. NCI Thesaurus. Code C51844.

An individual of a group united by a common factor; a person in a defined cohort or group of people. 